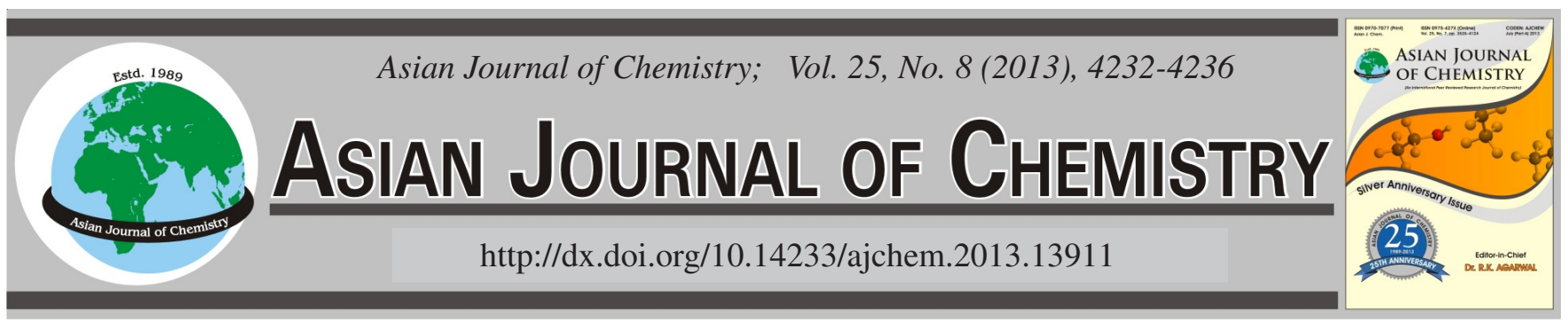

\title{
Assessment of Atmospheric Profile of Some Heavy Metals in Barks of Parkia biglobosa (African locust bean) Trees
}

\author{
S. Olatunji Olatunde ${ }^{1, *}$ and Osibanjo Oladele ${ }^{2}$
}

\begin{abstract}
${ }^{1}$ Department of Chemistry, Faculty of Applied Sciences, Cape Peninsula University of Technology, Bellville Campus, Western Cape, South Africa
\end{abstract} ${ }^{2}$ Department of Chemistry, Faculty of Science, University of Ibadan, Ibadan, Oyo State, Nigeria

*Corresponding author: Fax: +27 21 9598737; Tel: +27 822912934; E-mail: snf_olatunji@ymail.com

\begin{abstract}
Natural resource exploitation involving the mining of iron-ore from earth's deposits result in the release of aerodynamic size particulate metals, dusts and other atmospheric pollutants. The atmospherics baseline levels some iron-ore associated heavy metals were assessed around Itakpe iron-ore deposit, North Central Nigeria, using tree barks of African locust bean (Parkiabiglobosa) as indicator. Tree barks of $P$. biglobosa were randomly scaled off dried and digested using standard procedures. The digests were quantified for $\mathrm{Cd}, \mathrm{Mn}, \mathrm{Cr}, \mathrm{Ni}$, $\mathrm{Cu}, \mathrm{Zn}$ and $\mathrm{Pb}$ in flame of Unicam 969 atomic absorption spectrophotomer. The concentration of $\mathrm{Zn}, 20.387-52.07 \mathrm{mg} / \mathrm{kg}$ was the highest | in respect of other metals determined, followed by $\mathrm{Mn}, 8.74-24.18 \mathrm{mg} / \mathrm{kg}$ and then $\mathrm{Pb}, 2.95-8.66 \mathrm{mg} / \mathrm{kg}$. Cu levels ranged 0.68-3.14 mg/ kg, Ni, 0.34-3.12 mg/kg and Cr, 0.34-0.91 mg/kg. Cd concentration was the least; $0.16-0.48 \mathrm{mg} / \mathrm{kg}$ in barks of $P$. biglobosa trees. The overall mean concentrations (mg/kg) were: $\mathrm{Zn}, 34.21 \pm 4.09 ; \mathrm{Mn}, 13.59 \pm 2.04 ; \mathrm{Pb}, 25 \pm 0.75 ; \mathrm{Cu}, 1.34 \pm 0.34 ; \mathrm{Ni}, 1.18 \pm 1.05 ; \mathrm{Cr}, 0.55$ \pm 0.09 ; and $\mathrm{Cd}, 0.33 \pm 0.06$, with availability sequence is in the order $\mathrm{Zn}>\mathrm{Mn}>\mathrm{Pb}>\mathrm{Cu}>\mathrm{Ni}>\mathrm{Cr}>\mathrm{Cd}$. The detected heavy metals levels in the barks of $P$. biglobosa trees were variable, and may be a function of vegetation proximity/orientation to source points, plant distribution/population density, level of exposure and atmospheric stability, which is dependent on prevailing climatic factors. The evaluated $P$. biglobosa barks did not contain the heavy metals at concentrations capable of impacting negatively on the plant. Thus, the tree barks concentration of the evaluated metals were within natural concentration levels, and are therefore regarded as not polluted. This implies that atmospheric levels of the aerodynamic particulates heavy metals were low and not hazardous. The detected levels could serve as baseline concentration for monitoring against potential atmospheric deposit build up of heavy metals when mining becomes fully operational.
\end{abstract}

Key Words: Atmospheric, Aerodynamic size, Particulate, Heavy metals, Tree barks, Baseline levels.

\section{INTRODUCTION}

Activities arising from human exploitation of natural resources have greatly impacted on the environment. At the root of the impacts were the growing changes in technological knowledge and applications which end up with stress of contaminants on the environment. Environmental problems such as pollution of air ${ }^{1,2}$, water and soil have become important $t^{3,4}$ as a result of their harmful health effects. Forest and wildlife populations are confronted with a bewildering array of pollutants that are released into the environment ${ }^{5}$. Although air burden of contaminants may be eased within immediate environment, long range trans-boundary transport of contaminant can constitute problems; hence air burden of both short and long-range contaminants should be kept as low as possible.

The main air quality issue in mining industry is from the working of open pits, crushing and grinding operations which lead to the generation of dust and particulates ${ }^{6}$. Dusts and particulates emissions consisting of heavy metals, fugitive emissions, asbestos, cyanide and other air borne chemicals/ toxic materials from mining, ore beneficiation processes and tailing dams can be significant and especially more intense within confined spaces and living areas close to mine sites/ beneficiation plants ${ }^{6,7}$. Particle fall-out (mine dust) around mine sites can contaminate soils and water and damage vegetation ${ }^{6,8}$. Consequently, both terrestrial and aquatic environments receive atmospheric deposition of air borne metal pollutants from mining industries. Preliminary data of some industrial discharges showed elevated concentrations of heavy elements 5-20 times background levels and strong evidence for post depositional diffusion/mobility ${ }^{9-11}$.

Plants are important member of terrestrial ecosystem representing a major pathway for material biogeochemical cycle. It occupies strategic position in ecosystem's energy distribution structure being primary producers and could be a major source of exposure to different heterotrophs since food 
intake is one major route of exposure of higher heterotrophs and humans to most chemical substances ${ }^{12,13}$. Contamination resulting from heavy metals can lead to poor plant growth, as a result of their cytotoxic effects. Gene mutations may also be induced in plant protoplasm by chemical mutagenesis, and this can be permanent, thereby constituting a threat to food security and/or subsequent loss of habitat. Thus, residue of bioactive substances and their metabolites transported in air must be monitored because when bioactive metal contaminants present in plants are ingested by a component in the ecosystem, there is every likely hood of spread up the heterotrophic levels ${ }^{13,14}$.

The use of plants as environmental bio-indicators in ecological studies is scientifically accepted ${ }^{15-17}$. Lower plants such as mosses and lichens have been used as bio-indicators of heavy metals in soil environment because of their high capacity for accumulation $^{18,19}$. The past few decades saw the use of higher plants as bio-indicators for atmospheric monitoring of heavy metals ${ }^{15,16,20}$, which hitherto are largely monitored by passive sampling. The evaluation of atmospheric levels of heavy metals in the environment using barks of trees as indicator provides active information on exposure and the probable amount trapped by plants via aerial deposition and adsorption on plant surfaces. Sawidis et al. ${ }^{17}$ highlighted on various evergreen trees used as bio-monitors for air and soil pollution in urban environments and noted that plants bears the advantage of high spatial and temporal resolution due to availability and low sampling cost, coupled with wide distribution ${ }^{21}$ and long live which can facilitate repetition of investigation and monitoring time trend distribution of particulates heavy metals.

In this study, an extensive baseline concentration assessment of some selected heavy metals in barks of Parkia biglobosa (locust bean) tree was carried out around Itakpe iron ore deposit in North Central Nigeria. The result obtained may be used to define the baseline levels of the metals in plants because of their likely phytotoxicity, potential health risk associated with inhalation in air and injestion through local use of $P$. biglobosa barks in herbal therapy.

\section{EXPERIMENTAL}

Study area: Itakpe is located off the Lokoja-Okene transit route near Osara in North Central Nigeria. The study perimeter covers vegetation around footages areas of Itakpe iron ore deposit and the industrial area i.e. iron ores beneficiation plant embedded within Lokoja-Okene area, delimited by latitudes $7^{\circ}$ and $8^{\circ} \mathrm{N}$ and longitudes $6^{\circ}$ and $7^{\circ} \mathrm{E}$. Plant distribution assessment showed dominance of shrubs along with scattered deciduous trees around the Itakpe hill ranges. Soil cover structure is moderate as grasses are mostly restricted to the low type over the inter-twinned basement and sedimentary formation rocks. Hockey et al. ${ }^{22}$ reported that fringes along rivers and in steep slopes of cretaceous rocks outcrops overlying the basement consist of dense forest, especially in the southern valleys made up of patches of high forest on sediments terrain, although this is not extensive except around the southeast forest reserve.

Samples collection: Sampling was centred around the industrial area of the Nigerian Iron Ore Mining Project located on $\mathrm{N} 07^{\circ} 37,420^{\prime \prime}, \mathrm{E} 006^{\circ} 18,284^{\prime \prime}$ and altitude ranging from 241-325 metres of Itakpe iron ore mining field, North Central Nigeria, as shown in Fig. 1. The topographic inequalities of the land form and irregular vegetation distribution structure constrained systematic sampling, thus random sampling was adopted. The collection of samples spanned 24 months between 2003-2005 (dry and wet seasons), during which a total of 160 samples of tree bark of P. biglobosa (locust bean tree) were collected and processed.

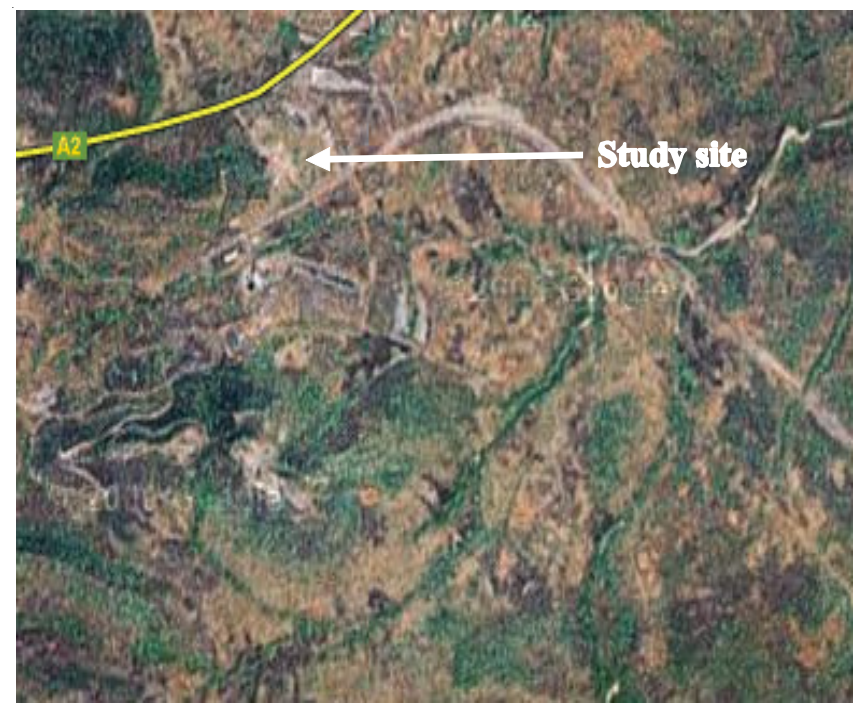

Fig. 1. Location map of the sampling area at Itakpe in Kogi State, North Central Nigeria

Sample digestion and analysis: The collected tree bark samples of $P$. biglobosa were air-dried in laboratory, crushed and blended to fine sizes using porcelain $\operatorname{mortar}^{23}$ and blender (National MX-491 N model) with stainless steel cutters. $1 \mathrm{~g}$ each of tree barks samples was weighed (Sauter Re: 1614 digital balance) into $100 \mathrm{~cm}^{3}$ kjeldahl flasks. $5 \mathrm{~mL}$ concentrated Analar grade nitric acid (British Drug House: BDH) was added to each and heated at $80{ }^{\circ} \mathrm{C}$ for $3 \mathrm{~h}^{23}$. The resulting digest solutions were filtered into $100 \mathrm{~mL}$ volumetric flask (Technico BS $1792 \mathrm{~B}$ in $20^{\circ} \mathrm{C}$ ) and made up to mark with distilled water. Procedural blank was prepared and aspirated in order to correct for background absorption. The digested sample solutions were quantified for $\mathrm{Cd}, \mathrm{Cr}, \mathrm{Mn}, \mathrm{Ni}, \mathrm{Cu}, \mathrm{Zn}$ and $\mathrm{Pb}$ in flame atomic absorption spectrometer (FAAS) (Unicam 969).

\section{RESULTS AND DISCUSSION}

Replicate analysis conducted on spiked tree bark samples showed good recoveries. The coefficient of variation of the spiked replicates lies between $1.40 \%$ and $18.25 \%$, with recoveries of 88.95-104.72\%. The recoveries of each of the metals tested were within the acceptable recovery limits of $100 \pm 20 \%$. The result of the determination of heavy metals concentrations in barks of $P$. biglobosa (locust bean) trees during dry seasons 2003/2004 and 2004/ 2005 and wet seasons during 2003/2004 and 2004/2005 are presented in Table- 1 .

The mean concentrations $(\mathrm{mg} / \mathrm{kg}$ ) of heavy metals (with range in parenthesis), in the barks of $P$. biglobosa tree during 


\begin{tabular}{|c|c|c|c|c|c|c|c|}
\hline \multicolumn{8}{|c|}{$\begin{array}{c}\text { TABLE- } 1 \\
\text { RANGES AND MEAN CONCENTRATIONS (mg/kg) OF HEAVY METALS IN BARKS } \\
\text { OF } \text { P. biglobosa TREES AROUND THE IRON ORE DEPOSIT }\end{array}$} \\
\hline $\begin{array}{l}\text { Sample identity } \\
\text { ITK/TB/D/03-04 }\end{array}$ & $\mathrm{Cd}(\mathrm{mg} / \mathrm{kg})$ & $\mathrm{Mn}(\mathrm{mg} / \mathrm{kg})$ & $\mathrm{Cr}(\mathrm{mg} / \mathrm{kg})$ & $\mathrm{Ni}(\mathrm{mg} / \mathrm{kg})$ & $\mathrm{Cu}(\mathrm{mg} / \mathrm{kg})$ & $\mathrm{Zn}(\mathrm{mg} / \mathrm{kg})$ & $\mathrm{Pb}(\mathrm{mg} / \mathrm{kg})$ \\
\hline Concentration range & $0.27-0.45$ & $8.74-10.40$ & $0.35-0.54$ & $0.68-1.34$ & $0.78-2.14$ & $24.88-35.06$ & $3.69-5.34$ \\
\hline $\begin{array}{l}\text { Mean (SD) } \\
\text { ITK/TB/D/04-05 }\end{array}$ & $0.37(0.06)$ & $9.50(0.56)$ & $0.43(0.06)$ & $1.08(0.23)$ & $1.38(0.47)$ & $30.96(2.75)$ & $4.49(0.54)$ \\
\hline Concentration range & $0.31-0.48$ & $10.28-24.18$ & $0.59-0.85$ & $1.60-3.12$ & $0.95-3.14$ & $39.64-52.07$ & $3.55-6.25$ \\
\hline $\begin{array}{l}\text { Mean (SD) } \\
\text { ITK/TB/W/03-04 }\end{array}$ & $0.39(0.05)$ & $17.97(4.03)$ & $0.75(0.07)$ & $2.30(0.49)$ & $2.05(0.56)$ & $45.89(4.19)$ & $22(0.78)$ \\
\hline Concentration range & $0.16-0.40$ & $8.97-12.21$ & $0.35-0.54$ & $0.34-1.05$ & $0.68-1.15$ & $20.87-31.24$ & $2.95-4.45$ \\
\hline $\begin{array}{l}\text { Mean (SD) } \\
\text { ITK/TB/W/04-05 }\end{array}$ & $0.27(0.07)$ & $10.92(1.03)$ & $0.45(0.06)$ & $0.58(0.16)$ & $0.92(0.15)$ & $26.00(3.42)$ & $3.95(0.37)$ \\
\hline Concentration range & $0.22-0.42$ & $11.43-19.48$ & $0.34-0.91$ & $0.48-1.21$ & $0.74-1.27$ & $25.14-45.95$ & $3.08-8.66$ \\
\hline Mean (SD) & $0.31(0.06)$ & $15.98(2.55)$ & $0.58(0.17)$ & $0.75(0.17)$ & $1.01(0.16)$ & $33.99(5.99)$ & $5.54(1.32)$ \\
\hline
\end{tabular}

year 2004-2005

dry season 2003/2004 were as follows: $\mathrm{Pb}, 4.49 \pm 0.54$ (3.695.34); $\mathrm{Cu}, 1.38 \pm 0.47$ (0.78-2.14); Ni, $1.08 \pm 0.23$ (0.68-1.34); $\mathrm{Zn}, 30.96 \pm 2.75$ (24.88-35.06); Cr, $0.43 \pm 0.06$ (0.35-0.54); $\mathrm{Mn}, 9.50 \pm 0.56$ (8.74-10.40); and Cd, $0.37 \pm 0.06(0.27-0.45)$ and during dry season 2004/2005: Pb, $22 \pm 0.78$ (3.55-6.25); $\mathrm{Cu}, 2.05 \pm 0.56$ (0.95-3.14); Ni, $2.30 \pm 0.49$ (1.60-3.12); Zn, $45.89 \pm 4.19$ (39.64-52.07); Cr, $0.75 \pm 0.07$ (0.59-0.85); Mn, $17.97 \pm 4.03$ (10.28-24.18); and Cd, $0.39 \pm 0.05$ (0.31-0.48).

Also, the mean concentration levels $(\mathrm{mg} / \mathrm{kg})$ of heavy metals in barks samples during wet season 2003/2004 were: $\mathrm{Pb}, 3.95 \pm 0.37$ (2.95-4.45); Cu, $0.92 \pm 0.15$ (0.68-1.15); Ni, $0.58 \pm 0.16$ (0.34-1.05); Zn, $26.00 \pm 3.42$ (20.87-31.24); Cr, $0.45 \pm 0.06$ (0.35-0.54); Mn, $10.92 \pm 1.03$ (8.97-12.21); and $\mathrm{Cd}, 0.27 \pm 0.07$ (0.16-0.40), while result for wet season 2004/ 2005 were: $\mathrm{Pb}, 5.54 \pm 1.32$ (3.08-8.66); $\mathrm{Cu}, 1.01 \pm 0.16(0.74-$ 1.27); Ni, $0.75 \pm 0.17$ (0.48-1.21); Zn, $33.99 \pm 5.99$ (25.1445.95); Cr, $0000.58 \pm 0.17$ (0.34-0.91); Mn, $15.98 \pm 2.55$ (11.43-19.48); and Cd, $0.31 \pm 0.06$ (0.22-0.42). Bark concentrations of $\mathrm{Zn}$ and $\mathrm{Mn}$ generally showed the highest concentration variability.

The concentration of $\mathrm{Zn}(20.387-52.07 \mathrm{mg} / \mathrm{kg})$ was the highest in respect of other metals determined, followed by $\mathrm{Mn}, 8.74-24.18 \mathrm{mg} / \mathrm{kg}$ and then $\mathrm{Pb}, 2.95-8.66 \mathrm{mg} / \mathrm{kg}$. Copper levels ranged $0.68-3.14 \mathrm{mg} / \mathrm{kg}, \mathrm{Ni}, 0.34-3.12 \mathrm{mg} / \mathrm{kg}$ and $\mathrm{Cr}$, $0.34-0.91 \mathrm{mg} / \mathrm{kg}$. Cd concentration was the least; $0.16-0.48$ $\mathrm{mg} / \mathrm{kg}$ in barks of $P$. biglobosa trees (Table-1). The overall mean concentrations $(\mathrm{mg} / \mathrm{kg})$ were: $\mathrm{Zn}, 34.21 \pm 4.09 ; \mathrm{Mn}$, $13.59 \pm 2.04 ; \mathrm{Pb}, 25 \pm 0.75 ; \mathrm{Cu}, 1.34 \pm 0.34 ; \mathrm{Ni}, 1.18 \pm 1.05$; $\mathrm{Cr}, 0.55 \pm 0.09$; and $\mathrm{Cd}, 0.33 \pm 0.06$, with availability sequence in the order $\mathrm{Zn}>\mathrm{Mn}>\mathrm{Pb}>\mathrm{Cu}>\mathrm{Ni}>\mathrm{Cr}>\mathrm{Cd}$. The detected heavy metals levels in barks of $P$. biglobosa trees were variable and probably a function of the following factors: atmospheric stability which relies on prevailing climatic factors, plant distribution and population density within an habitat, proximity, orientation/exposure to anthropogenic source points, plant ages and response.

The observed result in this study is consistent with findings of Aksoy et al. ${ }^{16}$ who reported Cd, $0.61 \pm 0.08 \mathrm{mg} / \mathrm{kg} ; \mathrm{Zn}$, $36.00 \pm 2.75 \mathrm{mg} / \mathrm{kg}$; with higher concentration for $\mathrm{Pb}, 27.04$ $\pm 3.01 \mathrm{mg} / \mathrm{kg}$ and $\mathrm{Cu}, 10.48 \pm 1.14 \mathrm{mg} / \mathrm{kg}$ in barks of Robinia pseudo-acacia trees collected in a suburban environment in
Turkey. Bark tissues of street tree Sophora japonica was reported to accumulate $\mathrm{Pb}, 11.0-199.0 \mathrm{mg} / \mathrm{kg}$ and $\mathrm{Ni}, 15.0$ $169 \mathrm{mg} / \mathrm{kg}^{20}$, which are several folds higher than found in this study. Sardans and Penuelas ${ }^{24}$ also reported low levels for Mn, $0.016-0.07 \mathrm{mg} / \mathrm{kg}$ in plant samples collected from different areas in Spain than observed in this study. Kakulu ${ }^{8}$ reported high concentration levels of $\mathrm{Cu}, 12.0 \pm 4.0 \mu \mathrm{g} / \mathrm{g} ; \mathrm{Pb}, 133.0 \pm$ $32.0 \mu \mathrm{g} / \mathrm{g} ; \mathrm{Zn}, 61.0 \pm 10.0 \mu \mathrm{g} / \mathrm{g} ;$ and Ni, $13.0 \pm 3.0 \mu \mathrm{g} / \mathrm{g}$ above natural concentrations in tree bark samples from commercial high traffic areas in different districts of Abuja, Nigeria than levels found in this study, for which automobile emissions was indicted and with low levels $\mathrm{Cd}, 0.3 \pm 0.2 \mu \mathrm{g} / \mathrm{g}$ comparable with study report.

However, the detected levels of heavy metals in barks of $P$. biglobosa trees were below the probable plants phytotoxic concentrations, Cd, 5-700 mg/kg; Cr, 1-10 mg/kg; Ni, 10-100 $\mathrm{mg} / \mathrm{kg} ; \mathrm{Zn},>100 \mathrm{mg} / \mathrm{kg}$; Cu, 20-100 mg/kg and Pb, 30-300 $\mathrm{mg} / \mathrm{kg}$ reported by Kabata-Pendias and Pendias ${ }^{18}$ and Boularbah et al. ${ }^{25}$. Therefore, the levels of heavy metals observed in barks of P. biglobosa trees around the iron ore deposit do not occur at concentrations injurious to both plants and consequently humans. This suggests that the levels of metals were within normal concentrations range for healthy plant growth.

The levels of heavy metals in barks and other plant surfaces are exacerbated by aerodynamic deposition. Some metals such as primary, secondary and essential micro/macro-nutrients are important to health and proper metabolism in living organisms such as in plants and animals, while some others are clearly toxic. Heavy metals present in trans-located alongside mineral nutrients may be accounted for by the relative amount found resident within different plant organs depending on their ecophysiological peculiarity and metabolic activities ${ }^{26,27}$. For metals such as $\mathrm{Pb}, \mathrm{Cr}, \mathrm{Cu}$ and $\mathrm{Fe}$, bark concentrations may be predictive of atmospheric deposition, because these metals tend to accumulate in the root and are scarcely trans-located into above ground organs ${ }^{18,27}$. Thus the amount of bio-available heavy metals trans-located to above ground plant organs is determined their concentration in the rooting zone ${ }^{28-30}$ and plant selective preference for heavy metals. Lindberg $^{1}$ and $\mathrm{Nriagu}^{31}$ reported that residual quantities of heavy metals in the barks 
of deciduous trees are largely a function of contamination from atmospheric sources. Linberg ${ }^{1}$ also noted that surface absorption by leaves and barks contributes to the total metal loads in plants. Apparently the detected heavy metal levels were not totally from aerial deposit, but additive with contribution from immobilized natural concentrations and from normal plant uptake.

Aerial adsorption of particulate metals by tree barks accounts for their aerodynamic depositional levels which in turns measures atmospheric quality for particulates metals. It was observed that bark levels of metals vary with season in that surface wetting result in the washing off of particulate metals loosely adhered to plant surfaces leading to concentration reduction. This probably accounts for the slightly higher concentration levels of heavy metals observed in barks of $P$. biglobosa tree during dry season except for $\mathrm{Pb}, \mathrm{Cr}$ and $\mathrm{Mn}$, while $\mathrm{Cd}$ levels was only slightly affected by changes in seasonal climate (Fig. 2). This observation is consistent with the findings of Boularbah et al. ${ }^{25}$.

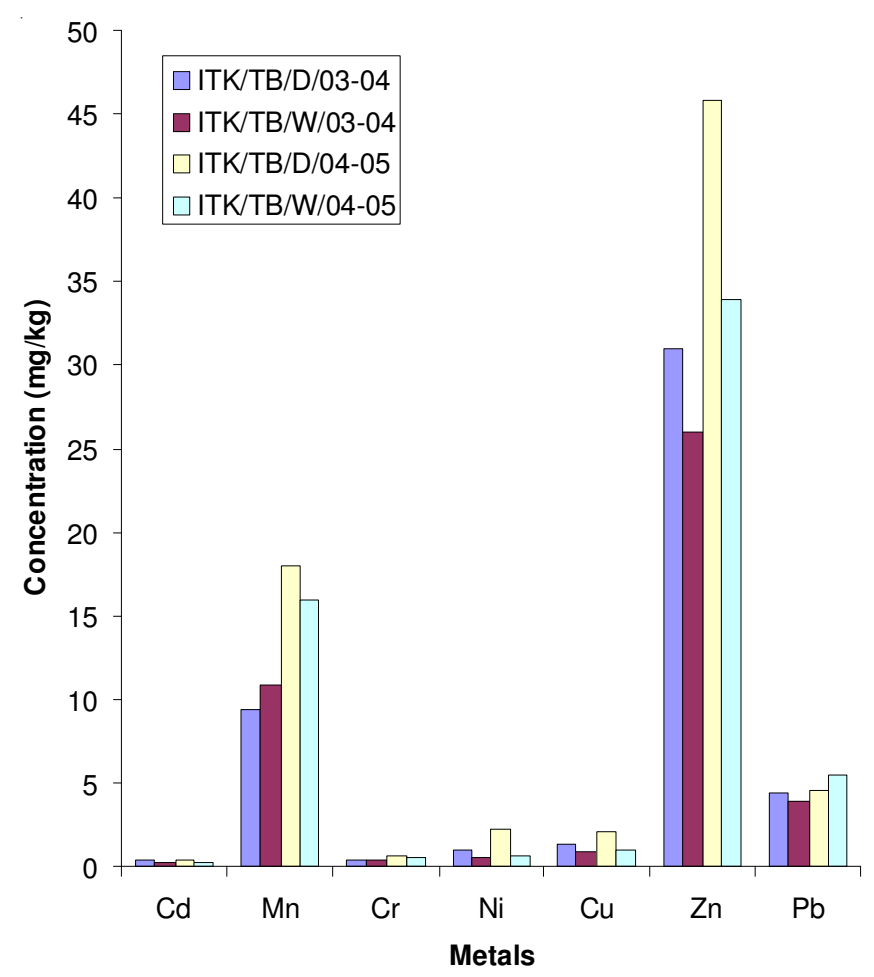

Fig. 2. Concentration levels $(\mathrm{mg} / \mathrm{kg}$ ) variations of heavy metals in bark of $P$. biglobosa (locust bean) tree during different climatic seasons; Code ITK = Itakpe; TB = tree bark of P. biglobosa $; \mathrm{D}=$ dry season; $\mathrm{W}=$ wet season; 03-04 = year 2003-04; 04-05 = year 2004-05

The atmospheric stability of the study area largely controls flux density of metals particulates in air within the different atmospheric boundary layers and is not known to be stable due to differential turbulence caused by the sun's heating effect on the area unequal topographic sequenced earth's surface, similar to the observation of Fernando et al.$^{32}$. Atmospheric stability also influences long distance trans-boundary transport of particulates metals. Consequently the levels of metal particulates in the atmosphere and the depth of the mixing layers will depends on rates of emission from sources and the prevailing weather conditions. Parlange and Brutsaert ${ }^{33}$ suggested that during windy and/or cloudy conditions, the atmosphere is normally neutral. Thus predicting air quality and flux concentration of metals using passive method can be misleading as a result of atmospheric instability. Aside from weather conditions, variation in barks concentration levels of heavy metals in plants is also function of biogeochemical and hydro-geochemical processes and balances ${ }^{34-36}$ and this largely controls metal levels and availability in the environment as well $^{37,38}$.

However owing to the fact that mining operations at the iron ore deposit is abysmally low, erratic and demand base, the observed levels in the barks can be taken as the natural aerial flux density of the measured metals defining the natural atmospheric quality of particulate metals around Itakpe iron ore deposit in North Central Nigeria.

\section{Conclusion}

The concentration levels of heavy metals in barks of $P$. biglobosa were found to fall below or within the levels detected elsewhere in the world. The detected levels can be taken as baseline concentrations against which environmental build up heavy metals in plants can be monitored. Active monitoring setup should be in operational, residential and vegetated areas to ensure human and environmental health and safety. This should take into cognizance distances and prevailing direction of air current. There is also need to identify the most sensitive short and long range receptors of atmospheric deposition of particulate metals and other releases from mine locations.

\section{REFERENCES}

1. S.E. Lindberg, Emission and Deposition of Atmospheric Mercury Vapour, in Lead, Mercury, Cadmium and Arsenic in the Environment, John Wiley and Sons, Ltd., New York, pp. 91-106 (1987).

2. R. Bargagli, Trace Element in Terrestrial Plant: An Ecophysiological Approach to Biomonitoring and Biorecovery, Springer-Verlag Berlin (1998).

3. N.E. Korte, J. Skopp, W.H. Fuller, E.E. Neible and B.A. Alesie, Soil Sci., 122, 223 (1975).

4. P.S. Klassen, J.E. Mclean, P.R. Grossl and R.L. Siws, J. Environ. Qual., 29, 1826 (2000).

5. D. Jay, in eds.: P. Moyle and D. Kelt, Wildlife and Pollution, Chapter 11 accessed from http://marinebio.org/oceans/conservation/moyle/ ch11. asp. on February 29, 2012 (1992)

6. UNEP, Ind. Environ., 23, 5 (2000).

7. N. Robins and R. Kumar, Health: Creating healthy cities in the $21 \mathrm{st}$ Century, World Health Organisation, New York, p. 235 (1995).

8. S.E. Kakulu, Earth Environ. Sci., 89, 1573 (2004).

9. J.O. Nriagu and J.M. Pacyna, Nature, 333, 134 (1988).

10. B. Lubkert and S. Zick de Tilly, Atmos. Environ., 23, 3 (1989).

11. Final Technical Report on Estimate Background Concentrations for the National-Scale Air Toxics Assessment: Emissions, Monitoring and Analysis Division Office of Air Quality Planning and Standards U.S. Environmental Protection Agency Research Triangle Park, North Carolina, 27711 (2003).

12. M. Brown, Laying Waste: The poisoning of America by Toxic Chemicals, Pantheon Books, New York (M, 1979).

13. EEC, European Community Official J., 26, 43 (1980).

14. L. Friberg and M. Vahter, Environ. Res., 30, 95 (1983).

15. B. Markert, Plants as Biomonitor VCH Publications, Weinhem, p. 664 (1995).

16. A. Aksoy, U. Sahin and F. Duman, Turk. J. Bot., 24, 279 (2000).

17. T. Sawidis, J. Breute, M. Mitrovic, P. Pavlovic and K. Tsigaridas, Environ. Pollut., 159, 3560 (2011)

18. K.-P. Alina and H. Pendias, Trace Element in Soils and Plants, CRC Press, Boca Raton, Florida, USA, edn 3 (2001).

19. S.J. Salami, J. Chem. Soc. Nigeria, 30, 47 (2005). 
20. U. Bingol, F. Geven and K. Guney, Kastamonu Univ. J. For. Fac., 8, 93 (2008).

21. T. Sawidis, J. Breuste, M. Mitrovic, P. Pavlovic and K. Tsigaridas, Environ. Pollut., 159, 3560 (2011).

22. R.D. Hockey, R. Saachi, W.P.F.H. Luar de Graaff and E.O.G. Muotoh, Geol. Surv. Nigeria Bull. No, 39, 71 (1986).

23. P. Wang, E. Qu, Z. Li and L.M. Shuman, J. Environ. Qual., 26, 795 (1997).

24. J. Sardans and J. Penuelas, Chemosphere, 60, 1293 (2005).

25. A. Boularbah, C. Schwartz, G. Bitton, W. Aboudrar, A. Ouhammou and J.L. Morel, Chemosphere, 6, 811 (2006).

26. G. Sarrett, A. Manceau, D. Cuny, C. Van Haluwyn, S. Deruella, J.I. Hazemann, Y. Soldo, L. Eybert-Berard and J.J. Menthonnex, Environ. Sci. Technol., 32, 3325 (1998).

27. G. Baycu, D. Tolunay, H. Ozden and S. Gunebakan, Environ. Pollut., 143, 545 (2006).

28. F.T. Scherer, B. Seelig and D. Franzen, Soil, Water and Plant Characteristics Important to Irrigation (Eb 66) (1996): Accessed from www.ag.ndsu.edu/pubs/ageng/irrigate/eb66w.htm on March 01 (2012).

29. E. Etxeberria, E. Baroja-Fernandez, F.J. Muñoz and J. Pozueta-Romero, Plant and Cell Physiol., 46, 474 (2005).

30. C.S. Hodges, Soil Fertility Basics. NC Certified Crop. Training on Soil Science Extension, North Carolina State University (2009).

31. J.O. Nriagu, Environment, 32, 7 (1990).

32. H.J.S. Fernando, S.M. Lee, J. Anderson, M. Princevac, E. Pardyjak and S. Grossman-Clarke, Environ. Fluid Mech., 1, 107 (2001).
33. M.B. Parlange and W. Brutsaert, Regional Roughness of the Landes Forest and Surface Shear Stress Under Neutral Conditions (1988).

34. D.H. Speidel and A.F. Agnew, The Natural Geochemistry of Our Environment, Westview Special Studies in Natural Resources and Energy Management (1982).

35. I. Thorton, P.W. Abrahams, E. Culbard, J.A.P. Rother and B.H. Olson, The Interaction Between Geochemical and Pollutant Metal Sources in the Environment: Implications for the Community, Applied Geochemistry in the 1980's, ed. I.Thorton and R.J. Howarth, Graham and Trotman Limited, Publishers (1986).

36. C. Keller, F.L. Domergue and J.C. Vedy, Biogeochemistry of Copper and Cadmium in Unpolluted Forests, Impact of Heavy Metals on the Environment, Trace Metals in the Environment, J.-P. Vernet, Elsevier Science Publishers, edn. 2, pp. 247-271 (1992).

37. A. Demetriades, Development of Integrated Collaborative Research Programs Between the U.K. (BGS) and Greece (IGME): Environmental Geochemistry Lavreotiki, Peninsula and Multidisciplinary Data Interpretation. Eastern Macedonia and Thrace Inst. Geol. Min, Expl: Athens, Greece, Open File Report E6700 vol. 1, text p. 165, vol. 2: Maps Diagrams and Tables, p. 128 (in English) (1992).

38. A.G. Darnley, A. Bjorklund, B. Belviken, N. Gustavsson, G. Koval and G.E.M. Hall, A Global Geochemical Database for Environmental and Resource Management. Recommendations for International Geochemical Mapping, Final Report of IGCP Project, 259, IGU Earth Science Paris: UNESCO (1995) 